\title{
Process Simulation and Environmental Assessment of the Production of Dimethyl Ether from Digestate
}

\author{
Aristide Giuliano, Enrico Catizzone* \\ ENEA-Italian National Agency for New Technologies, Energy and Sustainable Economic Development, DTE-BBC, Trisaia \\ Research Centre, I-75026, Rotondella, Italy
}

Corresponding Author Email: enrico.catizzone@enea.it

https://doi.org/10.18280/ti-ijes.642-407

Received: 17 February 2020

Accepted: 8 May 2020

Keywords:
dimethyl ether, digestate, OFMSW, techno-
environmental assessment, process
simulation

\section{Keywords:}

environmental assessment, process

simulation

\begin{abstract}
DME is considered a valuable energy vector, as it may be produced from biomass or waste and it may be used as alternative fuel. DME is currently produced from fossil sources, such as coal or natural gas. The utilization of streams derived from waste management as carbon source for producing chemicals is a reliable strategy for replacing fossil fuels and reducing carbon dioxide emissions in the atmosphere. In this work, a techno-environmental assessment for dimethyl ether production from digestate of organic fraction of municipal solid waste is presented and discussed. In particular, the indirect synthesis of dimethyl ether was assessed by considering the syngas produced via gasification of digestate. The carbon footprint calculated shows an environmental benefit equal to $1.1 \mathrm{kgCO}_{2} \mathrm{eq} / \mathrm{MJ}$.
\end{abstract}

\section{INTRODUCTION}

World energy demand is strongly increasing. The continue grow of the world's population, the enhancement of welfare, industrialization and fast-growing emerging economies development (e.g. China, India) cause a continue grow in the demand of energy [1]. In this concern, the transport sector accounts for almost two-thirds of the total liquid fuels demand. The demand of liquid fuel for transport application is strongly increasing because the sharp increasing in vehicle ownership number in emerging economies by passing by around one billion of vehicles to around 2.5 billion in just twenty years in the world due the fast economy growing mainly of China and India. This high growth rate of energy demand is in contrast with the necessity to reduce carbon emission, aimed to minimize the impact of energy utilization on the environment. For these reasons, the production of transport fuels from renewable and eco-friendly sources (solar, wind, water, tides, biomass or waste) is quickly increasing during the next twenty-thirty years, although fossil sources are still the most used energy sources (more than $80 \%$ ), mainly due to economic reasons [2].

In this concern, the production of dimethyl ether (DME) from renewables or waste permits to obtain an alternative fuel for Diesel engines, with its high cetane number $(>55)$ and a high well-to-wheel efficiency compared with other fuel (i.e. methane, ethanol, and Fisher-Tropsch fuel). Furthermore, DME represents a reliable environmentally friendly fuel due to the significant reduction of NOx emissions and total absence of SOx and particulate matter in engines exhaust gases respect to conventional diesel fuel $[3,4]$.

Dimethyl ether (DME) is the simplest of ether with molecular formula $\mathrm{C}_{2} \mathrm{H}_{6} \mathrm{O}$. DME is a colorless, non-toxic, noncorrosive and non-carcinogenic molecule with a normal boiling point of $-25^{\circ} \mathrm{C}$ that can be liquefied above $0.5 \mathrm{MPa}$ at ambient temperature. Physical properties of DME are similar to those of LPG, and the technologies developed for storage and transport of LPG can be easily converted to accommodate DME with similar safety guidelines and codes [5]. DME is also an important chemical intermediate to produce a wide variety of chemicals, such as diethyl sulphate, methyl acetate and light olefins [6,7]. Nowadays, DME is mainly used as an aerosol propellant in several spray cans, replacing the banned ozone-destroying CFC compounds but in the last decades, it is receiving a growing attention as an alternative eco-friendly fuel. In 1995, an extensive collaborative research effort among Amoco (actual BP), Haldor Topsoe and Navistar International Corporation, demonstrated that DME could be a reliable alternative fuel for diesel engines with low-emission of NOx, SOx and particular matter, manufacturable at large-scale from methanol by a simple dehydration technology [8]. These studies remarked the outstanding performances of DME as a diesel alternative fuel and showed total compliance with the most stringent California ULEV (ultra-low emission vehicle) emission regulations for medium-duty vehicles. Because the necessity to change the fuel distribution infrastructures and the modifications to engine devices, DME market as diesel alternative fuel was challenging. Indeed, the primary DME market was the blending of with LPG cut because of their very similar chemical-physical properties. For instance, Amoco patented a DME/LPG blend for automotive application [9]. The current key markets for DME as fuel are (1) blending with LPG, (2) alternative fuel for diesel engines, (3) fuel for power generation by gas turbines plant, and (4) chemical intermediate for olefins and synthetic-gasoline production.

DME can be produced from a variety of feed-stock including natural gas, coal, crus-oil residual oil and biomass. First, raw-materials are converted into synthesis gas (syngas), a mixture of hydrogen, carbon monoxide, and carbon dioxide. The fossil-derived hydrocarbons (e.g. natural gas, oil or coal) can be converted to syngas by well-known technologies. Steam reforming is the most used way to produce syngas by 
adopting reaction temperature and reaction pressure in the range of $700-900^{\circ} \mathrm{C}$ and $30-50$ bar, respectively, by using a nickel-based catalyst [10]. The production cost of syngas strongly depends on the price of raw material and its market economy. Syngas can be produced also by non-fossil sources. For instance, gasification of biomass or waste (thermal or catalytic) is a sustainable way to produce syngas [11-15]. After syngas production, DME synthesis can be performed in two different ways. One way is a conventional two-step process (indirect synthesis) which consists in the methanol synthesis from syngas followed by methanol dehydration in two distinct reactors; the other way is a one-step process (direct synthesis) which directly produces DME from syngas in a single reaction unit [16]. Indirect synthesis way is the most consolidated process for dimethyl ether production at industrial scale.

Indirect synthesis is the traditional way to produce DME. This route consists on methanol dehydration reaction reported below:

\section{$2 \mathrm{CH}_{3} \mathrm{OH}=\mathrm{CH}_{3} \mathrm{OCH}_{3}+\mathrm{H}_{2} \mathrm{O}$.}

Methanol dehydration is an exothermic reversible reaction $\left(-\Delta \mathrm{H}^{\circ}{ }_{298 \mathrm{~K}}=23.5 \mathrm{~kJ} / \mathrm{mol}\right)$ that proceeds without mole number variation. For this reason, operation pressure does not affect equilibrium conversion while low reaction temperatures have a thermodynamic benefit toward DME production. Methanol dehydration is a reaction catalyzed by acid catalysts and several investigations have been published in order to individuate an active, selective and stable catalyst at relative low temperature for the above-mentioned thermodynamic advantages. Depending on catalyst characteristics, methanol dehydration can be carried out in both vapor and liquid phase, with reaction temperature in the range $100-300^{\circ} \mathrm{C}$ and pressure up to 20 bar. $\gamma-\mathrm{Al}_{2} \mathrm{O}_{3}$ is the traditional catalyst for vapor phase methanol dehydration.

In the direct synthesis way methanol synthesis (typically from a $\mathrm{CO} / \mathrm{CO}_{2} / \mathrm{H}_{2}$ mixture) and methanol dehydration step to produce dimethyl ether are carried out in one-pot process over a redox/acid catalyst.

Table 1 reports the reactions set concerning direct synthesis process with the related reaction heats.

Table 1. Reactions set of direct synthesis of DME

\begin{tabular}{lcc}
\hline & Reaction & Reaction Heat [kJ/mol] \\
\hline (a) & $\mathrm{CO}_{2}+3 \mathrm{H}_{2}=\mathrm{CH}_{3} \mathrm{OH}+\mathrm{H}_{2} \mathrm{O}$ & -49 \\
(b) & $\mathrm{CO}+2 \mathrm{H}_{2}=2 \mathrm{CH}_{3} \mathrm{OH}$ & -91 \\
(c) & $2 \mathrm{CH}_{3} \mathrm{OH}=\mathrm{CH}_{3} \mathrm{OCH}_{3}+\mathrm{H}_{2} \mathrm{O}$ & -24 \\
(d) & $\mathrm{CO}+\mathrm{H}_{2} \mathrm{O}=\mathrm{CO}_{2}+\mathrm{H}_{2}$ & -41 \\
\hline
\end{tabular}

The main steps occurring during the direct synthesis process are usually the synthesis of methanol by hydrogenation of $\mathrm{CO}_{2}$ (a) or $\mathrm{CO}$ (b) over redox catalytic function, methanol dehydration to DME over acid function (c) and eventual water gas shift reaction (WGSR) catalysed by the redox function (d). The traditional catalyst for the direct synthesis of DME is a redox/acid bifunctional catalyst operating at reaction condition similar to those adopted for methanol synthesis $\left(250-280{ }^{\circ} \mathrm{C}\right.$ and $5-10 \mathrm{MPa})$. A redox function is necessary to promote methanol formation and acid function necessary to dehydrate the alcohol to the ether. The traditional catalyst for methanol synthesis $\mathrm{Cu} / \mathrm{Zn} / \mathrm{Al}_{2} \mathrm{O}_{3}(\mathrm{CZA})$ is used as redox function for methanol synthesis, combined with $\gamma-\mathrm{Al}_{2} \mathrm{O}_{3}$ or zeolites to produce DME [17-22].

It is important to remark that the market of dimethyl ether is strongly affected by production costs as well as by price, availability, accessibility and safety of the starting raw material. In this concern the utilization of waste as carbon source to produce syngas for DME synthesis is a scenario to merit at least a techno-environmental assessment. The global solid waste generation by urban residents is expected to increase from 3.5 Mtons/day in 2010 to 6.1 Mtons/day in 2025, with a total management cost of $\$ 375$ billion in 2025 [23]. Therefore, the management of MSW is a very challenging issue to be addressed. Municipal solid waste may be considered as a valuable source of carbon usable for both energy and chemicals production. Incineration/thermovalorization of MSW is the major solution adopted for unsorted MSW. On the contrary, an efficient MSW collection and sorting of MSW is the first step for recovering or recycling high-added value products pushing towards a circular economy system. In fact, the organic fraction of municipal solid waste (OFMSW) may be used as feedstock for anaerobic digestion. Anaerobic digestion is a process which not only reduces the amount of organic waste, i.e. organic fraction of MSW (OFMSW), sewage sludge, livestock manure and so on, but also produces energy in the form of biogas [24]. Biogas, the primary end-product of the anaerobic digestion process is a mixture of methane and carbon dioxide $\left(\mathrm{CH}_{4} / \mathrm{CO}_{2}\right.$ molar ratio ranges from 1.1 to about 2.5) with minor quantities of nitrogen, hydrogen sulfide and volatile organic compounds. Biogas is usually used as fuel in combined heat and power plants [25] or upgraded to produce bio-methane for automotive sector. In addition to biogas, digestate containing a high amount of non-biodegradable components is also produced from an anaerobic digestion process. Currently, digestate is mainly used as nitrogen-rich organic fertilizer, avoiding the use of mineral fertilizers for agricultural soil. Nevertheless, in the last decade, the number of anaerobic digestion plants is growing significantly, causing also a significant growth of digestate production which need to be valorized in alternative way. In this regard, gasification may be used to produce syngas from digestate [26].

In this work, a process simulation of the production of dimethyl ether via indirect synthesis way is presented by adopting a syngas composition equals to that obtained from digestate gasification. The aim of the study is to assess the environmental impact in terms of equivalent carbon dioxide emission of the investigated case, pushing towards a waste-tochemicals scenario.

\section{MATERIALS AND METHODS}

Process design tools [27] were used in order to identify all process streams of plants to valorise syngas obtained by digestate gasification.

As previously reported, gasification-deriving syngas can be used to produce either energy or high-added value products, such as chemicals or fuels. In this section indirect DME synthesis scenario is assessed according to the scheme reported in Figure 1.

For the calculations, a syngas with produced via digestate gasification with composition and properties equal to that used in a previous work, was adopted [28]. The molar composition of the adopted syngas is reported in Table 2.

A commercial software was used to carry out the process simulations. Redlich-Kwong-Soave thermodynamic equation of state was adopted to simulate high-pressure systems, while NRTL-RK was used for distillation columns and flash separation units. 


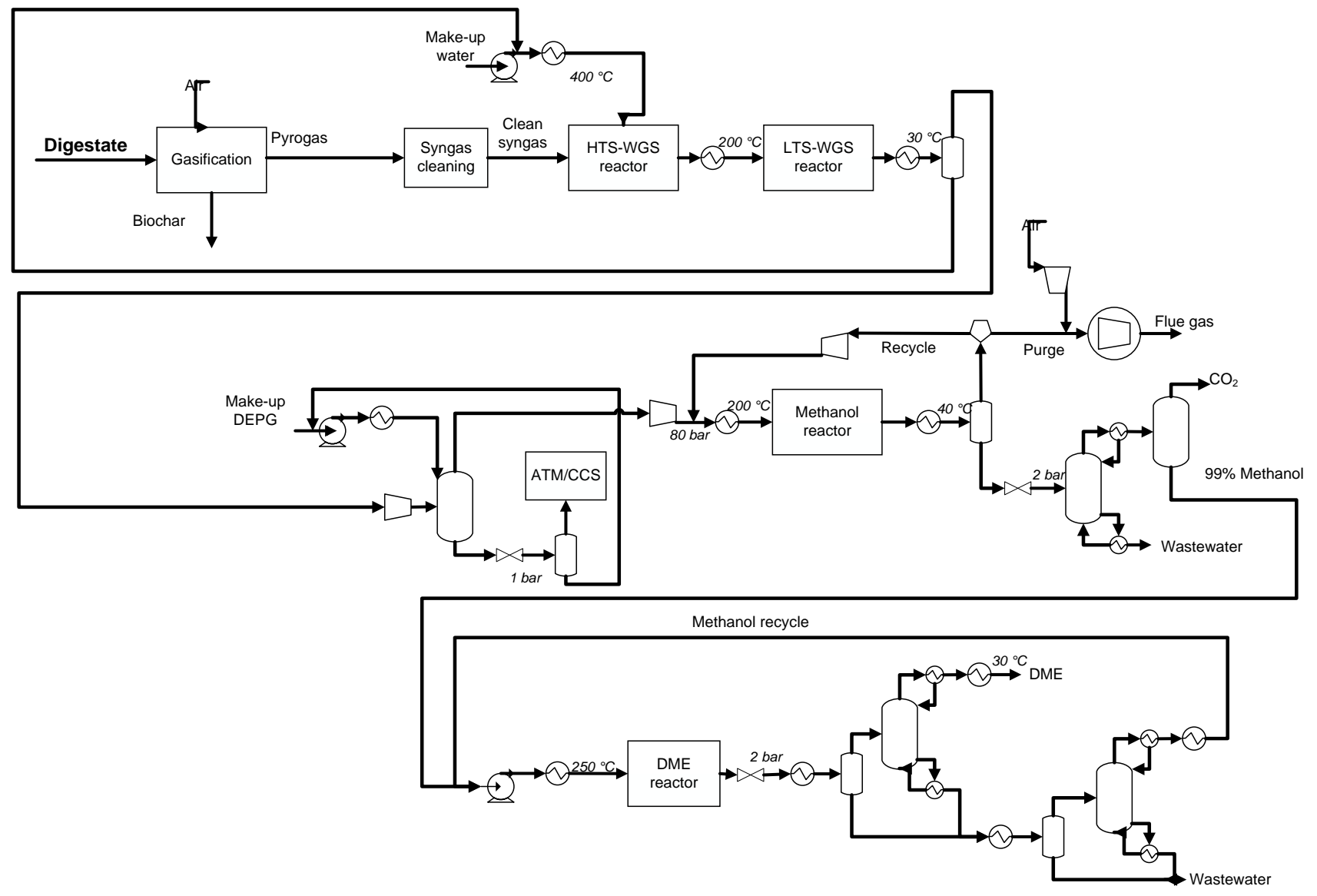

Figure 1. Process flowsheet for the indirect DME-synthesis case

Table 2. Syngas composition (\%voldry $)[28]$

\begin{tabular}{cc}
\hline $\mathrm{H}_{2}$ & 11.9 \\
$\mathrm{CO}$ & 13.7 \\
$\mathrm{CO}_{2}$ & 12.9 \\
$\mathrm{CH}_{4}$ & 4.5 \\
$\mathrm{C}_{2} \mathrm{H}_{6}$ & 1.3 \\
$\mathrm{~N}_{2}$ & 55.7 \\
\hline
\end{tabular}

\section{WGS section}

As reported in Table 2, the $\left(\mathrm{H}_{2}-\mathrm{CO}_{2}\right) /\left(\mathrm{CO}+\mathrm{CO}_{2}\right)$ in the produced syngas is close to zero, therefore an upgrading section is requested in order to increase the hydrogen content $[29,30]$. The upgrading system consists of a catalytic unit for hydrogen production and a carbon dioxide capture.

In this regard, the high-pressure capture of carbon dioxide and the production of methanol require the conversion of carbon monoxide and steam into $\mathrm{CO}_{2}$ and $\mathrm{H}_{2}$, coming with the clean syngas stream, by means of the Water Gas Shift (WGS) reaction:

\section{$\mathrm{CO}+\mathrm{H}_{2} \mathrm{O}=\mathrm{CO}_{2}+\mathrm{H}_{2}$}

The WGS reaction is carried out in two steps, namely High Temperature Shift (HTS) and Low Temperature Shift (LTS). Temperature was set to $400{ }^{\circ} \mathrm{C}$ and $200{ }^{\circ} \mathrm{C}$ for HTS and LTS, respectively. Similar conditions are adopted for industrial processes, where $\mathrm{Fe}_{2} \mathrm{O}_{4} / \mathrm{Cr}_{2} \mathrm{O}_{3}$ and $\mathrm{Cu}-\mathrm{ZnO}-\mathrm{Al}_{2} \mathrm{O}_{3}$ are used as catalysts for HTS and LTS, respectively. This sequence allows to take advantage of the faster conversion rate in the HTS path and to finally approach a higher equilibrium conversion value (larger than 99\%) for the most favourable equilibrium conditions in the LTS. The pressure of WGS unit was assumed equal to the pressure of methanol synthesis, which was set at 80 bar [15].

The main operating parameter of this process is the steamto-carbon monoxide molar ratio (SC). It was assumed that the clean gas is mixed with a superheated steam available at $400{ }^{\circ} \mathrm{C}$ and $80 \mathrm{bar}$. In particular, for an energetic point of view, the pumping of a liquid is more convenient than the compression of a vapour. Therefore, it was assumed that liquid water available at room temperature was pumped up $80 \mathrm{bar}$ and then heated in a heat exchanger unit to obtain the superheated steam required by the water gas shift reaction.

The steam flowrate was chosen to obtain a SC equal to 2.5. The two fixed bed reactors of waster gas shift unit were modelled as equilibrium reactors. The pressure drop in the sequence of the two catalytic fixed bed, was assumed of about 2 bar [29].

The gas stream leaving the two WGS stages is cooled down to $30^{\circ} \mathrm{C}$ to condense the steam. The condensed water is then recovered, recycled, mixed to a make-up water stream and sent to the pumping unit/heat exchanger for the production of the superheated steam.

\section{$\mathrm{CO}_{2}$ capture section}

The water gas shift unit increases both the hydrogen and the carbon dioxide content. Therefore, the $\left(\mathrm{H}_{2}-\mathrm{CO}_{2}\right) /\left(\mathrm{CO}+\mathrm{CO}_{2}\right)$ is not affected. Hence, a carbon dioxide unit is requested in order to remove a proper amount of carbon dioxide in order to obtain a syngas composition suitable for methanol synthesis.

In this paper, the separation of $\mathrm{CO}_{2}$ from the enriched syngas stream is carried out by absorption in the proprietary solvent Selexol ${ }^{\circledR}$, a mixture of dimethyl ethers of polyethylene glycol $\left(\mathrm{CH}_{3} \mathrm{O}\left(\mathrm{C}_{2} \mathrm{H}_{4} \mathrm{O}\right) \mathrm{nCH}_{3}\right)$, where "n" is between 3 and 9 , in 
a packed tower with $75 \mathrm{~mm}$ IMTP $®$ packing of Koch-Glitsch ${ }^{\circledR}$. Because the absorption is favoured at high pressure, the syngas produced from the water gas shift unit available at 80 bar and $30^{\circ} \mathrm{C}$, is directly sent to the absorption tower.

The Selexol® solvent is then compressed up 80 bar by means a pump and sent to the top of the tower at $30^{\circ} \mathrm{C}$. Solvent regeneration is carried out downstream the absorption tower to separate the absorbed carbon dioxide. The regenerated solvent is then recycled. However, a small make-up stream is necessary to replace the solvent entrained in the gaseous stream leaving the packed tower. In particular, the regeneration is performed by lowering the pressure in two stages by means of two expansion valves up to 1 bar.

In particular, a flash seperator is used to recover the $\mathrm{CO}_{2}$ from the solvent. The regenerated solvent is mixed with the make-up stream and recycled back to the absorption tower after proper recompression and cooling. From an environmental point of view, low pressure $\mathrm{CO} 2$ is considered to be (i) emitted in the atmosphere or (ii) stored.

In the last case, the recovered $\mathrm{CO}_{2}$, which has a purity usuful for selling (at least $98.5 \%$ by weight), is compressed up to 110 bar by a compressor train, formed by three compression stage with intercooling by two heat exchangers.

\section{DME synthesis}

Methanol synthesis reactions [29] were adopted to simulate methanol synthesis via both $\mathrm{CO}$ and $\mathrm{CO}_{2}$ hydrogenation. Because methanol formation is an exothermic reaction, methanol synthesis is favoured at low temperature, from a thermodynamic point of view. Inlet stream to methanol reactor is mixed with recycle stream (unreacted syngas), heated up to $200{ }^{\circ} \mathrm{C}$ and fed to the methanol synthesis adiabatic reactor. An equilibrium reactor was adopted for the methanol synthesis unit. A pressure drop equal to 2 bar was assumed along the reactor. Concerning operating pressure, an 80 bar pressure is considered to favour thermodynamics. Similar values are also adopted at industrial scale.

The output stream of methanol synthesis reactor was cooled down at $40^{\circ} \mathrm{C}$ by a heat exchanger and the light gases are separated in a flash-phase-separator. A part of the separated gases was re-compressed at 80 bar and recycled to the reactor, while the rest was used as fuel for electricity production. The liquid streams, mainly consists of methanol and water, was expanded in a throttling valve at 2 bar and distilled in a tray column to separate the wastewater from methanol. Liquid pure methanol was the pumped until to 30 bar and then heated to $250^{\circ} \mathrm{C}$ for the DME synthesis, which is carried out in a secondary fixed bed reactor (maximum pressure drop of 2 bar) modelled, even in that case, as an equilibrium reactor.

The DME-rich stream was the expanded to recovery DME in the vapour phase. Due to traces of methanol, this stream was sent to a distillation column to obtain pure DME.

Column bottom stream was sent to another distillation column to recycle unconverted methanol.

\section{Environmental impact analysis}

For the process case, a final environmental impact analysis was performed in terms of total $\mathrm{CO}_{2}$-equivalent emission by adopting the values reported in Table 3. In particular, a negative $\mathrm{CO}_{2}$-equivalent emission value is associated with digestate, by considering the $\mathrm{CO}_{2}$ emitted from the landfill for the digestate disposal. The electricity production saving was considered equal to that of the fossil-based energy production system.
The main direct $\mathrm{CO}_{2}$ emission point is the-flue gases of the combustion of purge gas.

Table 3. $\mathrm{CO}_{2}$ equivalent emission parameters

\begin{tabular}{cc}
\hline Process item & $\mathrm{CO}_{2}$ equivalent emission \\
\hline Digestate $\left(\mathrm{kg}_{\mathrm{CO} 2 \mathrm{eq}} / \mathrm{t}\right)[31]$ & $-1^{\prime} 821$ \\
Green electricity $\left(\mathrm{kgCO}_{\mathrm{eq}} / \mathrm{MWhe}\right)$ & -600 \\
{$[31]$} & $1^{\prime}, 913$ \\
DME final use $\left(\mathrm{kg}_{\mathrm{CO} 2 \mathrm{eq}} / \mathrm{t}\right)$ & 6.5 \\
Process water $\left(\mathrm{kg}_{\mathrm{CO} 2 \mathrm{eq}} / \mathrm{t}\right)[31]$ & 500 \\
Wastewater $\left(\mathrm{kg}_{\mathrm{CO} 2 \mathrm{eq}} / \mathrm{t}\right)$ & $1^{\prime} 821$ \\
Biochar residual $\left(\mathrm{kg}_{\mathrm{CO} \mathrm{eq}} / \mathrm{t}\right)[31]$ &
\end{tabular}

Equivalent $\mathrm{CO}_{2}$ emissions of DME were calculated considering its final combustion, if it is used as a fuel: from 1 mole of DME 2 moles of $\mathrm{CO}_{2}$ are produced by combustion.

\section{RESULTS AND DISCUSSION}

A plant size equal to $100^{\prime} 000 \mathrm{t} / \mathrm{y}$ of digestate was considered as collective digestate treatment plant.

Table 4 shows the process parameter values obtained by simulations. Global CO conversion on WGS section was equal to $56 \% \mathrm{~mol}$, that is sufficient to remove $35.5 \mathrm{kt} / \mathrm{y}$ of $\mathrm{CO}_{2}$ by Selexol ${ }^{\circledR}$, which corresponds to removing level of $90 \%$ of $\mathrm{CO}_{2}$ from the $\mathrm{H}_{2}$-rich stream. The carbon capture makes possible obtaining a $\left(\mathrm{H}_{2}-\mathrm{CO}_{2}\right) /\left(\mathrm{CO}+\mathrm{CO}_{2}\right)$ molar ratio equal to 2 , suitable for the methanol synthesis. The global conversion of $\mathrm{CO}+\mathrm{CO}_{2}$ to $\mathrm{MeOH}$ was about $54 \%$ (thanks to the syngas recycle) with a methanol production of $4.8 \mathrm{kt} / \mathrm{y}$.

A purge split ratio equal to $10 \%$ was set in order to keep equal to 2 the $\left(\mathrm{H}_{2}-\mathrm{CO}_{2}\right) /\left(\mathrm{CO}+\mathrm{CO}_{2}\right)$ molar ratio in the reactor inlet.

The reaction conversion of $\mathrm{MeOH}$ to $\mathrm{DME}$ was equal to $88 \%$ (equilibrium value) with a production of about $3.2 \mathrm{kt} / \mathrm{y}$ of dimethyl ether.

Also, the electricity production was considerable. Purge gas was used in an engine to produce electricity and thermal energy for the heat integration. Electricity consumption of compressors and chiller to cool final DME condenser decreased the gross electricity from 7.4 MWe to $2 \mathrm{MWe}$.

The environmental assessment results shown in Table 5, highlights the environmental benefit of the proposed process scheme. The emissions of the plant derived by char disposal and direct $\mathrm{CO}_{2}$ in the flue gases, essentially. This thanks to the captured $\mathrm{CO}_{2}$ by Selexol ${ }^{\circledR}$, after increasing of $\mathrm{CO}_{2}$ partial pressure by WGS section. The biggest $\mathrm{CO}_{2 \text { eq }}$ saving value corresponds to avoided digestate disposal for a total of 182 $\mathrm{kt} / \mathrm{y}$ of $\mathrm{CO}_{2 \mathrm{eq}}$. The second biggest saving was for the green electricity production $\left(8.6 \mathrm{kt}_{\mathrm{CO} 2 \mathrm{eq}} / \mathrm{y}\right)$, due to the high specific saving of $600 \mathrm{~kg}_{\mathrm{CO} 2 \mathrm{eq}} / \mathrm{MWhe}$.

Table 4. Process simulation main results

\begin{tabular}{cc}
\hline Process parameter & Value \\
\hline $\mathrm{CO}_{2}$ captured by Selexol ${ }^{\circledR}(\mathrm{kt} / \mathrm{y})$ & 35.5 \\
$\mathrm{CO}$ conversion in HT-WGS reactor $(\% \mathrm{~mol})$ & 31 \\
$\mathrm{CO}$ conversion in LT-WGS reactor $(\% \mathrm{~mol})$ & 33 \\
Global CO+CO $\mathrm{CO}_{2}$ conversion to $\mathrm{MeOH}(\% \mathrm{~mol})$ & 54 \\
$\mathrm{MeOH}$ conversion to DME $(\% \mathrm{~mol})$ & 88 \\
DME production $(\mathrm{kt} / \mathrm{y})$ & 3.2 \\
Net electricity production $(\mathrm{MWe})$ & 2.0 \\
\hline
\end{tabular}


Table 5. Annual $\mathrm{CO}_{2}$ equivalent emissions. Negative values are $\mathrm{CO}_{2}$ savings

\begin{tabular}{cc}
\hline Process item & $\mathbf{C O}_{2}$ equivalent emission $\left(\mathrm{ktCO}_{2} / \mathbf{y}\right)$ \\
\hline Digestate & -182 \\
Char to disposal & 71 \\
Wastewater & 0.8 \\
Process water & 0.07 \\
$\mathrm{CO}_{2}$ in flue gas & 23 \\
DME & 6.2 \\
Net electricity & -8.6 \\
\hline Total & -89.8 \\
\hline
\end{tabular}

The global result was for about $89.8 \mathrm{kt}_{\mathrm{CO} 2 \mathrm{eq}} / \mathrm{y}$ of missed emissions and it depends by digestate utilization, essentially.

Finally, specific $\mathrm{CO}_{2}$ saving is equal to $0.97 \mathrm{kgCO}_{2 \mathrm{eq}} / \mathrm{MJ}$ by considering the indirect synthesis of DME from digestatederived syngas. Considering the emissions of diesel are equal to $0.099 \mathrm{kgCO} 2 / \mathrm{MJ}$ [32], a total saving of $1.07 \mathrm{kgCO}_{2}$ eq $/ \mathrm{MJ}$ was obtained.

Without considering the environmental benefit of digestate utilization, a positive global emission derived by DME production is obtained, i.e. $+0.99 \mathrm{kgCO}_{2}$ eq $/ \mathrm{MJ}$. The syngas quality is not optimal for an industrial synthesis without considering a waste raw material. Low global yield to DME (3.2 $\mathrm{kgDME} / \mathrm{kgdigestate)}$ and high compression power make the process less convenient. In general, the DME production by the indirect synthesis can be considered when the raw material is a waste and energy for the compression of syngasto-methanol has a low cost.

\section{CONCLUSIONS}

In this work the indirect synthesis of DME was assessed considering as solid feedstock the digestate derived by anaerobic digestion. In particular, the syngas derived by gasification of digestate was sent to 3 sections: WGS, carbon capture and $\mathrm{MeOH} / \mathrm{DME}$ synthesis.

Results show the process is convenient from a technoenvironmental point of view. A final $\mathrm{CO}_{2 \text { eq }}$ saving of 0.97 $\mathrm{kgCO}_{2 \text { eq }} / \mathrm{MJ}$ was obtained. This value is lower than the environmental impact of fossil-based diesel $(+0.099$ $\mathrm{kgCO}_{2 \mathrm{eq}} / \mathrm{MJ}$ ).

Finally, digestate is a good feedstock to obtain an environmental benefit, but low yield to products can make noeconomically convenient the global process.

\section{REFERENCES}

[1] BP Energies Outlook, 2016 Ed.

[2] Ellabban, O., Abu-Rub, H., Blaabjerg, F. (2014). Renewable energy resources: Current status, future prospects and their enabling technology. Renewable and Sustainable Energy Reviews, 39: 748-764. https://doi.org/10.1016/j.rser.2014.07.113

[3] Semelsberger, T.A., Borup, R.L., Greene, H.L. (2006). Dimethyl ether (DME) as an alternative fuel. Journal of power sources, 156(2): 497-511. https://doi.org/10.1016/j.jpowsour.2005.05.082

[4] Arcoumanis, C., Bae, C., Crookes, R., Kinoshita, E. (2008). The potential of di-methyl ether (DME) as an alternative fuel for compression-ignition engines: A review. Fuel, 87(7): 1014-1030 https://doi.org/10.1016/j.fuel.2007.06.007
[5] Ogawa, T., Inoue, N., Shikada, T., Ohno, Y. (2003). Direct dimethyl ether synthesis. Journal of natural gas chemistry, 12(4): 219-227.

[6] Park, S.Y., Shin, C.H., Bae, J.W. (2016). Selective carbonylation of dimethyl ether to methyl acetate on Ferrierite. Catalysis Communications, 75: 28-31. https://doi.org/10.1016/j.catcom.2015.12.006

[7] Catizzone, E., Cirelli, Z., Aloise, A., Lanzafame, P., Migliori, M., Giordano, G. (2018). Methanol conversion over ZSM-12, ZSM-22 and EU-1 zeolites: from DME to hydrocarbons production. Catalysis Today, 304: 39-50. https://doi.org/10.1016/j.cattod.2017.08.037

[8] Fleisch, T.H., Basu, A., Sills, R.A. (2012). Introduction and advancement of a new clean global fuel: The status of DME developments in China and beyond. Journal of Natural Gas Science and Engineering, 9: 94-107. https://doi.org/10.1016/j.jngse.2012.05.012

[9] US Patent 5, 632, 786, May 27, 1997, A. Basu et al. (Eds.).

[10] LeValley, T.L., Richard, A.R., Fan, M. (2014). The progress in water gas shift and steam reforming hydrogen production technologies-a review. International Journal of Hydrogen Energy, 39(30): 16983-17000. https://doi.org/10.1016/j.ijhydene.2014.08.041

[11] Barisano, D., Canneto, G., Nanna, F., Alvino, E., Pinto, G., Villone, A., Battafarano, A., Braccio, G. (2016). Steam/oxygen biomass gasification at pilot scale in an internally circulating bubbling fluidized bed reactor. Fuel Processing Technology, 141: 74-81. https://doi.org/10.1016/j.fuproc.2015.06.008

[12] Safarian, S., Unnpórsson, R., Richter, C. (2019). A review of biomass gasification modelling. Renewable and Sustainable Energy Reviews, 110: 378-391. https://doi.org/10.1016/j.rser.2019.05.003

[13] Sansaniwal, S.K., Pal, K., Rosen, M.A., Tyagi, S.K. (2017). Recent advances in the development of biomass gasification technology: A comprehensive review. Renewable and sustainable energy reviews, 72: 363-384. https://doi.org/10.1016/j.rser.2017.01.038

[14] Macrì, D., Catizzone, E., Molino, A., Migliori, M. (2020) Supercritical water gasification of biomass and agro-food residues: Energy assessment from modelling approach. Renewable $\quad$ Energy, 150: 624-636. https://doi.org/10.1016/j.renene.2019.12.147

[15] Giuliano A., Catizzone E., Barisano D., Nanna F., Villone A., De Bari I., Cornacchia G., Braccio G . (2019). Techno-environmental assessment for a bio-methanol integrated plant using anaerobic digestion Of OFMSW, carbon capture and biomass gasification, TECNICA ITALIANA-Italian Journal of Engineering Science, 63(2-4): 263-269. https://doi.org/10.18280/ti-ijes.632421

[16] Azizi, Z., Rezaeimanesh, M., Tohidian, T., Rahimpour, M.R. (2014). Dimethyl ether: A review of technologies and production challenges. Chemical Engineering and Processing: Process Intensification, 82: 150-172. https://doi.org/10.1016/j.cep.2014.06.007

[17] Catizzone, E., Bonura, G., Migliori, M., Braccio, G., Frusteri, F., Giordano, G. (2019). Direct CO2-todimethyl ether hydrogenation over $\mathrm{CuZnZr/zeolite}$ hybrid catalyst: New evidences on the interaction between acid and metal sites. Annales de Chimie-Science des Matériaux 4(3): 141-149. https://doi.org/10.18280/acsm.430302 
[18] Catizzone, E., Bonura, G., Migliori, M., Frusteri, F., Giordano, G. (2018). CO2 recycling to dimethyl ether: State-of-the-art and perspectives. Molecules, 23(1): 31. https://doi.org/10.3390/molecules23010031

[19] Migliori, M., Catizzone, E., Aloise, A., Bonura, G., Gómez-Hortigüela, L., Frusteri, L., Cannilla, C., Frusteri, F., Giordano, G. (2018). New insights about coke deposition in methanol-to-DME reaction over MOR-, MFI-and FER-type zeolites. Journal of Industrial and Engineering Chemistry, 68: 196-208. https://doi.org/10.1016/j.jiec.2018.07.046

[20] De Falco, M., Capocelli, M., \& Centi, G. (2016). Dimethyl ether production from $\mathrm{CO} 2$ rich feedstocks in a one-step process: thermodynamic evaluation and reactor simulation. Chemical Engineering Journal, 294: 400-409. https://doi.org/10.1016/j.cej.2016.03.009

[21] Venvik, H.J., Yang, J. (2017). Catalysis in microstructured reactors: Short review on small-scale syngas production and further conversion into methanol, DME and Fischer-Tropsch products. Catalysis Today, 285: 135-146. https://doi.org/10.1016/j.cattod.2017.02.014

[22] Perathoner, S., Centi, G. (2014). CO2 recycling: a key strategy to introduce green energy in the chemical production chain. ChemSusChem, 7(5): 1274-1282. https://doi.org/10.1002/cssc.201300926

[23] Hoornweg, D., Bhada-Tata, P. (2012). What a waste: A global review of solid waste management. Urban development series;knowledge papers no. 15. World Bank, Washington, DC. (C) World Bank. https://doi.org/10.1111/febs.13058

[24] Migliori, M., Catizzone, E., Giordano, G., Le Pera, A., Sellaro, M., Lista, A., Zanardi, G., Zoia, L. (2019). Pilot plant data assessment in anaerobic digestion of organic fraction of municipal waste solids. Processes, 7(1): 54. https://doi.org/10.3390/pr7010054

[25] Chow, W.L., Chong, S., Lim, J.W., Chan, Y.J., Chong, M.F., Tiong, T.J., Chin, J.K., Pan, G.T. (2020). Anaerobic co-digestion of wastewater sludge: A review of potential co-substrates and operating factors for improved methane yield. Processes, 8(1): 39. https://doi.org/10.3390/pr8010039

[26] Freda, C., Cornacchia, G., Romanelli, A., Valerio, V., Grieco, M. (2018). Sewage sludge gasification in a bench scale rotary kiln. Fuel, 212: 88-94. https://doi.org/10.1016/j.fuel.2017.10.013

[27] Giuliano, A., Poletto, M., Barletta, D. (2015). Process design of a multi-product lignocellulosic biorefinery. Computer Aided Chemical Engineering, 37: 1313-1318. https://doi.org/10.1016/B978-0-444-63577-8.50064-4

[28] Giuliano, A., Poletto, M., Barletta, D. (2018). Pure hydrogen co-production by membrane technology in an IGCC power plant with carbon capture. International Journal of Hydrogen Energy, 43(41): 19279-19292. https://doi.org/10.1016/j.ijhydene.2018.08.112

[29] Giuliano, A., Catizzone, E., Freda, C., Cornacchia, G. (2020). Valorization of OFMSW digestate-derived syngas toward methanol, hydrogen, or electricity: process simulation and carbon footprint calculation. Processes, 8(5): 526. https://doi.org/10.3390/pr8050526

[30] Giuliano, A., Freda, C., Catizzone, E. (2020). Technoeconomic assessment of bio-syngas production for methanol synthesis: A focus on the water-gas shift and carbon capture sections. Bioengineering, 7(3): 70. https://doi.org/10.3390/bioengineering7030070

[31] Pérez, J., de Andrés, J.M., Lumbreras, J., Rodríguez, E. (2018). Evaluating carbon footprint of municipal solid waste treatment: Methodological proposal and application to a case study. Journal of Cleaner Production, 205: 419-431. https://doi.org/10.1016/j.jclepro.2018.09.103

[32] Galanopoulos, C., Giuliano, A., Barletta, D., Zondervan, E. (2020). Chemical Engineering Research and Design an integrated methodology for the economic and environmental assessment of a biorefinery supply chain. Chemical Engineering Research and Design, 160: 199215. https://doi.org/10.1016/j.cherd.2020.05.016 